\title{
Perbedaan efek pemberian tunggal vitamin e dengan pemberian kombinasi vitamin e dan zink terhadap kualitas spermatozoa tikus wistar (Rattus Norvegicus) yang diberi paparan asap rokok
}

\author{
${ }^{1}$ Iis A. H. Silalahi \\ ${ }^{2}$ Grace L.A. Turalaki \\ ${ }^{2}$ Janette M. Rumbajan
}

\author{
${ }^{1}$ Kandidat Skripsi Fakultas Kedokteran Universitas Sam Ratulangi Manado \\ ${ }^{2}$ Bagian Biologi Fakultas Kedokteran Universitas Sam Ratulangi Manado \\ Email: iisarista77@yahoo.com
}

\begin{abstract}
Smoking can increase free radicals in sperm, which can damage sperm. Vitamin E as non-enzymatic antioxidant and zinc as enzymatic antioxidant that is effective in dealing with free radicals. The aim of this research was to look at the differences between the effects of vitamin $\mathrm{E}$ and zinc on spermatozoa quality of male wistar rats (Rattus norvegicus) after exposure to cigarette smoke. The research used a completely randomized experimental design. Samples were 9 male wistar rats (Rattus norvegicus) which were randomly divided into 3 groups. Each group was given exposure to cigarette smoke from 2 bars of cigarette/day, which treatment group $\left(\mathrm{P}_{1}\right)$ also was given vitamin E $1,44 \mathrm{mg} / \mathrm{day}$ and treatment group $\left(\mathrm{P}_{2}\right)$ also was given combination of vitamin $\mathrm{E} 1,44 \mathrm{mg} / \mathrm{day}$ and zinc 10 $\mathrm{mg} /$ day. The treatment was given for 50 days. The results of this research showed a significant difference in the motility and morphology of spermatozoa between the treatment group $\left(\mathrm{P}_{1}\right)$ which received exposure the cigarette smoke and vitamin $\mathrm{E}$ and treatment group $\left(\mathrm{P}_{2}\right)$ which received exposure to cigarette smoke and combination of vitamin $\mathrm{E}$ and zinc $(\mathrm{p}<0,05)$ compared with the group which received exposure only cigarette smoke without vitamin $\mathrm{E}$ or zinc. The motility of spermatozoa treatment group $\left(\mathrm{P}_{2}\right)$ which received exposure the cigarette smoke and combination vitamin $\mathrm{E}$ and zinc was found significant difference with the treatment group $\left(\mathrm{P}_{1}\right)$ which received exposure the cigarette smoke and vitamin $\mathrm{E}(\mathrm{p}$ $<0,05)$. Conclusion: The conclusion from this research showed that there is difference between spermatozoa quality especially motility and morphology of group treated with vitamin $\mathrm{E}$ and combination of vitamin $\mathrm{E}$ and zinc after exposure to cigarette smoke, with combination of vitamin $\mathrm{E}$ and zinc had an higher average on spermatozoa quality especially motility.
\end{abstract}

Keywords: vitamin E, zinc, cigarette smoke, quality of spermatozoa

\begin{abstract}
Abstrak: Merokok dapat menyebabkan peningkatan radikal bebas yang dapat merusak sperma. Vitamin E sebagai antioksidan non enzimatis dan zink sebagai antioksidan enzimatis merupakan antioksidan yang efektif dalam mengatasi radikal bebas. Tujuan penelitian ini adalah untuk melihat perbedaan efek antara pemberian vitamin $\mathrm{E}$ dan kombinasi vitamin $\mathrm{E}$ dengan zink terhadap kualitas spermatozoa tikus wistar (Rattus norvegicus) jantan setelah diberi paparan asap rokok. Penelitian ini menggunakan metode penelitian eksperimental dengan menggunakan rancangan acak legkap. Sampel yang digunakan adalah 9 tikus wistar (Rattus norvegicus) jantan yang dibagi secara acak menjadi 3 kelompok. Masing-masing kelompok tikus diberi paparan asap rokok 2 batang / hari dimana kelompok perlakuan $\left(\mathrm{P}_{1}\right)$ juga diberi vitamin E 1,44 mg/hari, dan kelompok perlakuan $\left(\mathrm{P}_{2}\right)$ diberi kombinasi vitamin $\mathrm{E}$ $1,44 \mathrm{mg} / \mathrm{hari}$ dan zink $10 \mathrm{mg} / \mathrm{hari}$. Perlakuan diberikan selama 50 hari. Hasil penelitian menunjukkan adanya perbedaan signifikan pada motilitas dan morfologi spermatozoa
\end{abstract}


kelompok perlakuan $\left(\mathrm{P}_{1}\right)$ dengan perlakuan paparan asap rokok dan vitamin $\mathrm{E}$ dan kelompok perlakuan $\left(\mathrm{P}_{2}\right)$ dengan perlakuan paparan asap rokok dan kombinasi vitamin $\mathrm{E}$ dengan zink dibandingkan dengan kelompok control $\left(\mathrm{P}_{0}\right)$ yang hanya mendapat paparan asap rokok $(\mathrm{p}<0,05)$. Motilitas spermatozoa kelompok perlakuan $\left(\mathrm{P}_{2}\right)$ didapati hasil yang berbeda signifikan dibandingkan dengan kelompok perlakuan $\left(\mathrm{P}_{1}\right)(\mathrm{p}<0,05)$. Simpulan: Kesimpulan dari penelitian ini didapatkan bahwa terjadi perbedaan signifikan kualitas spermatozoa yaitu pada motilitas dan morfologi antara pemberian tunggal vitamin $\mathrm{E}$ dan kombinasi vitamin $\mathrm{E}$ dengan zink setelah pemaparan asap rokok, dengan kombinasi vitamin $\mathrm{E}$ dan zink memiliki rata-rata kualitas spermatozoa lebih tinggi khususnya motilitas.

Kata kunci: vitamin E, zink, asap rokok, kualitas spermatozoa

Merokok merupakan salah satu gaya hidup yang lazim ditemui dalam kehidupan sehari - hari, meskipun memiliki berbagai dampak negatif terhadap kesehatan manusia. Di Indonesia, prevalensi perokok mencapai $36,3 \%$ dengan pekerjaan terbanyak adalah petani/nelayan/ buruh, yaitu sebesar 44,5 $\%{ }^{1}$

Rokok menghasilkan sekitar 4000 bahan kimia yang terbentuk melalui beberapa proses yaitu hidrogenasi, pirolisis, oksidasi, dekarboksilasi, dan dehidrasi. Diantara semua bahan kimia yang dihasilkan rokok, komponen utama yang paling membahayakan kesehatan adalah nikotin, tar, dan karbon monoksida. ${ }^{2}$

Asap rokok dapat menyebabkan peningkatan kadar Reactive Oxygen Species (ROS) dan penurunan antioksidan pada sperma, yang dapat mengganggu spermatogenesis. Hal ini mengakibatkan penurunan konsentrasi, motilitas normal spermatozoa, serta peningkatan abnormallitas morfologi spermatozoa. ${ }^{2,3}$

Beberapa penelitian menyebutkan bahwa vitamin $E$ dapat memperbaiki kualitas spermatozoa. ${ }^{3-5}$ Penelitian sebelumnya mengatakan bahwa vitamin $\mathrm{E}$ mengendalikan peroksidasi lipid oleh ROS dengan cara mengubah radikal peroksil menjadi radikal tokoferol sehingga tidak mampu merusak rantai PUFA yang penting dalam membran spermatozoa. ${ }^{6}$

Penelitian lain menyatakan dalam sistem reproduksi pria, zink berfungsi dalam mengatur kestabilan kromatin dan membran sel spermatozoa, melindungi testis dari perubahan degeneratif, serta sebagai antioksidan. ${ }^{7,8}$

Berdasarkan latar belakang diatas, penulis tertertarik untuk mengetahui perbedaan efek pemberian kombinasi vitamin $E$ dan mineral zink dengan pemberian tunggal vitamin $\mathrm{E}$ terhadap kualitas spermatozoa diantaranya konsentrasi, motilitas, dan morfologi wistar (Rattus norvegicus) yang diberi paparan asap rokok.

\section{METODE PENELITIAN}

Penelitian ini merupakan penelitian eksperimental dengan menggunakan rancangan acak lengkap. Penelitian dilakukan di laboratorium Biologi Fakultas Kedokteran Universitas Sam Ratulangi, dengan rentang waktu bulan September hingga November 2016.

Bahan yang digunakan dalam penelitian ini adalah bahan makanan dan minuman untuk tikus, rokok kretek, vitamin E kapsul, minyak wijen, zink tablet, akuades, bahan pemeriksaan kualitas sperma $(\mathrm{NaCl}$ fisiologis $0,9 \%$, methanol, larutan safranin, larutan kristal violet) dan hewan coba berupa tikus wistar jantan yang memenuhi kriteria inklusi, yaitu tikus wistar jantan berusia 12-14 minggu, berat badan 200-250 gram dan sehat, tingkah laku dan aktivitas tikus normal. Alat yang digunakan adalah kandang pemeliharaan, kandang perlakuan, sonde oral, bilik hitung hemasitometer Improved Neubauer, dissecting kit, kaca, kaca penutup, pipet tetes, cawan petri, mikroskop listrik, kamera digital dan timbangan digital.

Sampel penelitian ini berjumlah 9 ekor tikus wistar jantan (Rattus norvegicus) dibagi acak menjadi 3 kelompok, yaitu kelompok kontrol $\left(\mathrm{P}_{0}\right)$ hanya dengan paparan asap rokok 2 batang rokok/hari 
tanpa pemberian vitamin $\mathrm{C}$ dan vitamin $\mathrm{E}$, kelompok perlakuan $\mathrm{I}\left(\mathrm{P}_{1}\right)$ pemaparan asap rokok 2 batang rokok/hari dengan pemberian tunggal vitamin E $1,44 \mathrm{mg} /$ hari dan kelompok perlakuan II $\left(\mathrm{P}_{2}\right)$ pemaparan asap rokok 2 batang rokok/hari dengan pemberian vitamin E 1,44 mg/hari dan zink $10 \mathrm{mg} /$ hari.

Setelah hewan coba mengalami aklimatisasi selama satu minggu. Setiap perlakuan pemaparan asap rokok dilakukan dalam kandang perlakuan. Bagian ujung rokok yang dibakar dimasukkan ke dalam kandang perlakuan. Jika rokok telah habis terbakar, hewan coba dikeluarkan. Setelah itu diberikan vitamin $\mathrm{E}$ yang telah dilarukan dalam miyak wijen dan zink yang telah dilarutkan dalam akuades yang akan dimasukkan melalui sonde oral. Pemberian perlakuan dilakukan selama 50 hari.

Pada hari ke-51, hewan coba diterminasi menggunakan disecting kit untuk mengambil cauda epididimis. Selanjutnya cauda epididimis dimasukkan ke dalam cawan petri dan ditetesi $\mathrm{NaCL}$ $0,9 \%$ sebanyak 5 tetes. Suspensi sperma dari cauda epididimis ini yang digunakan untuk pengamatan kualitas spermatozoa hewan coba meliputi konsentrasi spermatozoa, motilitas spermatozoa dan morfologi spermatozoa.

\section{HASIL PENELITIAN}

Setelah dilakukan penelitian selama 50 hari pada 3 kelompok tikus wistar (Rattus norvegicus) yang telah diberikan paparan asap rokok dengan pemberian vitamin $\mathrm{E}$ tunggal ataupun kombinasi vitamin $\mathrm{E}$ dan zink didapatkan hasil rerata konsentrasi, motilitas dan morfologi spermatozoa masing-masing kelompok (Tabel 1).

Pada Tabel 2 dapat dilihat hasil uji komparabilitas kualitas spermatozoa antara $\mathrm{P}_{0}$ dan kualitas spermatozoa $\mathrm{P}_{1}$. Tidak terdapat perbedaan bermakna pada konsentrasi spermatozoa antara kelompok kontrol dan kelompok perlakuan 1 ( $p>0,05)$; terdapat perbedaan bermakna pada motilitas spermatozoa antara kelompok kontrol dan kelompok perlakuan $1(\mathrm{p}<0,05)$; terdapat perbedaan bermakna pada morfologi spermatozoa antara kelompok kontrol dan kelompok perlakuan $1(\mathrm{p}<0,05)$.

Tabel 1. Rerata konsentrasi, motilitas dan morfologi spermatozoa

\begin{tabular}{cccccc}
\hline Kelompok Sampel & Konsentrasi & \multicolumn{2}{c}{ Motilitas (\%) } & \multicolumn{2}{c}{ Morfologi (\%) } \\
\cline { 2 - 6 } & $\left(\mathbf{x} \mathbf{1 0}^{\mathbf{6}}\right.$ spermatozoa/ $\mathbf{~ m l )}$ & Normal & Abnormal & Normal & Abnormal \\
$\mathrm{P}_{0}$ & 58,5 & 17 & 83 & 77 & 23 \\
$\mathrm{P}_{1}$ & 76,3 & 30 & 70 & 93 & 7 \\
$\mathrm{P}_{2}$ & 150,2 & 60 & 40 & 93 & 7 \\
\hline
\end{tabular}

Keterangan: Kelompol P0, kelompok diberikan paparan asap rokok 2 batang / hari. Kelompok P1, kelompok yang diberikan paparan asap rokok 2 batang / hari dan pemberian tunggal vitamin E 1,44 $\mathrm{mg} /$ hari. Kelompok P2, kelompok yang diberikan paparan asap rokok 2 batang / hari dan pemberian kombinasi vitamin E $1,44 \mathrm{mg} / \mathrm{hari}$ dan zink $10 \mathrm{mg} / \mathrm{hari}$.

Tabel 2. Pengujian Rerata Kualitas Spermatozoa Kelompok Kontrol Terhadap Kelompok Perlakuan 1 Dengan Uji T.

\begin{tabular}{lccc}
\hline Kualitas Spermatozoa & Kelompok Kontrol & Kelompok Perlakuan 1 & nilai p \\
\hline Konsentrasi & $58,5 \times 10^{6}$ & $76,3 \times 10^{6}$ & 0,936 \\
Motilitas Normal & 17 & 30 & 0,007 \\
Morfologi Normal & 77 & 93 & 0,001 \\
\hline
\end{tabular}


Pada Tabel 3 dapat dilihat hasil uji komparabilitas kualitas spermatozoa antara $\mathrm{P}_{0}$ dan kualitas spermatozoa kelompok $\mathrm{P}_{2}$. Hasil uji T pada tabel 3 menunjukkan tidak terdapat perbedaan bermakna pada konsentrasi spermatozoa antara kelompok kontrol dan kelompok perlakuan 2 $(\mathrm{p}>0,05)$; terdapat perbedaan bermakna pada motilitas spermatozoa antara kelompok kontrol dan kelompok perlakuan $2(\mathrm{p}<0,05)$; terdapat perbedaan bermakna pada morfologi spermatozoa antara kelompok kontrol dan kelompok perlakuan $2(\mathrm{p}<0,05)$.
Pada Tabel 4 dapat dilihat hasil uji komparabilitas kualitas spermatozoa antara $\mathrm{P}_{1}$ dan kualitas spermatozoa kelompok $\mathrm{P}_{2}$. Tidak terdapat perbedaan bermakna konsentrasi spermatozoa antara kelompok perlakuan 1 dan kelompok perlakuan 2 ( $>0,05)$; terdapat perbedaan bermakna motilitas spermatozoa antara kelompok perlakuan 1 dan kelompok perlakuan 2 $(\mathrm{p}<0,05)$; tidak terdapat perbedaan bermakna morfologi spermatozoa antara kelompok perlakuan 1 dan kelompok perlakuan $2(\mathrm{p}>0,05)$.

Tabel 3. Pengujian Rerata Kualitas Spermatozoa Kelompok Kontrol Terhadap Kelompok Perlakuan 2 Dengan Uji T.

\begin{tabular}{lccc}
\hline Kualitas Spermatozoa & Kelompok Kontrol & Kelompok Perlakuan 2 & nilai $\mathbf{p}$ \\
\hline Konsentrasi & $58.5 \times 10^{6}$ & $150.2 \times 10^{6}$ & 0,073 \\
Motilitas Normal & 17 & 60 & 0,000 \\
Morfologi Normal & 77 & 93 & 0,000 \\
\hline
\end{tabular}

Tabel 4. Pengujian Rerata Kualitas Spermatozoa Kelompok Perlakuan 1 Terhadap Kelompok Perlakuan 2 Dengan Uji T.

\begin{tabular}{llll}
\hline Kualitas Spermatozoa & Kelompok Perlakuan 1 & Kelompok Perlakuan 2 & nilai p \\
\hline Konsentrasi & $76,3 \times 10^{6}$ & $150,2 \times 10^{6}$ & 0,107 \\
Motilitas Normal & 30 & 60 & 0,000 \\
Morfologi Normal & 93 & 93 & 1,000 \\
\hline
\end{tabular}

\section{BAHASAN}

Pada penelitian ini didapatkan hasil analisis yang menunjukkan terdapat perubahan hasil kualitas spermatozoa antara kelompok perlakuan 1 yang terhadap kelompok kontrol dan kelompok perlakuan 2 terhadap kelompok kontrol. Hasil analisis perbandingan kualitas spermatozoa antara kelompok kontrol dan kelompok perlakuan 1 dan antara kelompok kontrol dan kelompok perlakuan 2 menunjukkan ada perbedaan bermakna pada motilitas dan morfologi, tetapi tidak pada konsentrasi. Sedangkan perbandingan kualitas spermatozoa antara kelompok perlakuan 1 dan kelompok perlakuan 2 menunjukkan ada perbedaan bermakna pada motilitas, tetapi tidak pada konsentrasi dan morfologi.

Tidak ditemukannya perbedaan yang signifikan pada konsentrasi antara kelompok kontrol dan kelompok perlakuan 1 ataupun kelompok perlakuan 2 dikarenakan peranan antioksidan yang melindungi membran spermatozoa bukan pada organnya ${ }^{6}$

Adanya perbedaan bermakna antara kelompok kontrol dan kelompok perlakuan 1 pada motilitas dan morfologi dikarenakan peranan vitamin $\mathrm{E}$ sebagai antioksidan yang melindungi sperma dari radikal bebas yang dihasilkan oleh asap rokok. Vitamin E mengendalikan peroksida lemak dengan cara mengubah radikal peroksil menjadi radikal tokoferol sehingga tidak mampu merusak rantai PUFA yang penting dalam 
membran spermatozoa. ${ }^{6}$ Vitamin $\mathrm{E}$ juga mengendalikan kadar malondialdehyde dan 4-hydroxy, 2 neonenal ( 4 - HNE) pada sperma menjadi normal sehingga dapat meningkatkan motilitas sperma. Selain itu, vitamin $\mathrm{E}$ juga mengurangi fragmentasi DNA spermatozoa sehingga meningkatkan morfologi spema. ${ }^{7}$

Perbedaan bermakna antara kelompok kontrol dan kelompok perlakuan 2 pada motilitas dan morfologi, selain peranan vitamin $\mathrm{E}$, zink juga dapat meningkatkan kualitas spermatozoa. Selain sebagai antioksidan, Zink mengontrol penggunaan atau utilisasi energi melalui sistem adenosine riposphate (ATP) dan regulasi fosfolipid sehingga dapat meningkatkan motilitas spermatozoa. ${ }^{4}$ Selain itu zink juga mengatur kestabilan kromatin dan membran sel spermatozoa dan melindungi testis dari perubahan degeneratif., ${ }^{7,8}$

Hasil penelitian ini menunjukkan terjadinya peningkatan kualitas spermatozoa setelah pemberian vitamin $\mathrm{E}$ dan zink. Hal ini sesuai dengan beberapa penelitian sebelumnya yang menyebutkan bahwa pemberian vitamin $\mathrm{E}$ dan zink menunjukkan adanya peningkatan kualitas spermatozoa. ${ }^{4,5,7,8}$

Adanya perbedaan bermakna antara kelompok perlakuan 1 dan kelompok perlakuan 2 pada motilitas disebabkan peranan vitamin $\mathrm{E}$ dan zink pada kualitas spermatozoa dibandingkan pada kelompok yang hanya mendapat vitamin E saja.

Hasil penelitian ini menunjukkan terjadinya peningkatan kualitas spermatozoa lebih tinggi dengan pemberian kombinasi vitamin $\mathrm{E}$ dan zink dibandingkan pemberian tunggal vitamin $\mathrm{E}$ tunggal. Hal ini sesuai dengan penelitian sebelumnya. $^{4}$

\section{SIMPULAN}

1. Pemberian vitamin $\mathrm{E}$ menyebabkan peningkatan kualitas spermatozoa secara signifikan pada motilitas normal dan morfologi normal spermatozoa.
2. Pemberian kombinasi vitamin $\mathrm{E}$ dan zink meningkatkan kualitas spermatozoa secara signifikan pada motilitas normal spermatozoa dan morfologi normal spermatozoa.

3. Pemberian kombinasi vitamin $\mathrm{E}$ dan zink meningkatkan kualitas spermatozoa secara signifikan lebih tinggi dibandingkan dengan pemberian vitamin E secara tunggal pada motilitas.

\section{DAFTAR PUSTAKA}

1. Balitbang Kemenkes RI. Hasil Riset Kesehatan Dasar; RISKESDAS. Jakarta: Balitbang Kemenkes RI; 2013.

2. Hammond D, Fong GT, Cummings KM, O'Connor RJ, Giovino GA, McNeill A. Cigarette yields and human exposure: a comparison of alternative testing regimens. Cancer Epidomiol Biomarkers Prev 2006; 15: 1495-501.

3. Quaratul'ainy S. Pengaruh vitamin e terhadap jumlah spermatozoa mencit jantan starin balb/c yang diberi paparan asap rokok. Artikel kedokteran. Universitas Diponegoro Semarang; 2006[citied 2014 sep 14].

4. Surhayati S. Pengaruh penambahan vitamin e dan mineral zink terhadap kualitas semen serta fertilitas dan daya tetas telur kalkun lokal. J Indon Trop Anim Agric 2006; 31(3): 180-1.

5. Wang S, Wang G, Barton BE, Murphy TF, and Huang HF. Beneficial effects of vitamin $e$ in sperm functions in the rat after spinal cord injury. Journal of Andrology 2007; 28: 334-41.

6. Joanne Wen. The role of vitamin e in the treatment of male infertility. Nutrition Bytes 2006; 11(1).

7. Egwurugwu JN, Ifedi CU, Uchefuna RC, Ezeokafor EN, Alagwu EA. Effects of zinc on male sex hormones and semen quality in rats. Niger $\mathrm{J}$ Physiol Sci 2013; 28: 17-22.

8. Murarka S, Mishra V, Joshi P, and Kumar Sunil. Role of zinc in reproductive biology- an overview. Austin J Repro Med Infertil 2015; 2(2): 1009.

9. Agarwal Ashok, Sekhon Lucky H. The role of antioxidant therapy in treatment of male fertility. Human Fertility 2010; 13(4): 217-2. 